\title{
Women and Politics in Local Autonomy Era
}

\author{
Aniek Rakhmaniah \\ Doctoral Program of Social Science \\ Airlangga University \\ Surabaya, Indonesa \\ arahmaniah@pips.uin-malang.ac.id
}

\begin{abstract}
Indonesia's democratic transition, although on the one hand, successfully reforms women's political rights through the reform of constitutional mechanisms through constitutional reform as well as national legislation, such as quota-issue policy, but on the other hand fails to make substantial changes in the process of democratization. The issues of women are still seen as an issue of welfare which is closely related to poverty reduction and the protection of marginalized groups. The emphasis on women's experience is one of the feminist inputs, namely the concept of subjectivity. First, the discussion of the problem of subjectivity will examine the problem of role-taking and the creation of knowledge. Second, how people internalize the existing norms. Third, how self, selfhood is formed as a social actor. Fourth, is how the relationship between consciousness with everyday events. There are three records concerning the impact of regional autonomy on women. First, the tendency of strengthening of identity politics, politicization of religion, and cultural revitalization nuanced restriction public role of women. Second, regional autonomy does not necessarily improve the welfare of a community is characterized by more budget allocations for local government implementation costs than the welfare of the community. Third, the active participation of women in policy-making is still very minimal. There are several things women need to fight for, such as trying to develop public awareness that the policy-making process at the local level should involve all the elements. Then the need for awareness of all levels of society that women are the elements of society that become the main pillar in building local democracy, therefore the aspiration of women should be the main consideration in the process of policy making.
\end{abstract}

\section{Keywords—women, politics, women movement}

\section{INTRODUCTION}

The discourse on feminism has developed with the active participation of women in social and political movements for their political rights. This is related to the increasing movement of women's movement in a better shape of organization. In the last decade the women's movement has grown stronger with various models of struggle. Besides it is also a discourse on good governance, which is one of the basic principles are about the enforcement of Human Rights (HAM), including the rights of political participation for men and women alike, have inspired women to participate actively in the process political. Gender issues are now global, so the development of any political agenda should include the perspectives, ideas and experiences both men and women.

Yet despite all the efforts pioneered over the centuries by women's figures in the world, the recognition and implementation of political and socio-economic rights between men and women is still not balanced. Indonesia's democratic transition, although on the one hand, successfully reforms women's political rights through the reform of constitutional mechanisms through constitutional reform as well as national legislation, such as quota-issue policy, but on the other hand fails to make substantial changes in the process of democratization. The issues of women are still seen as an issue of welfare which is closely related to poverty reduction and the protection of marginalized groups. The anti-violence programs against women, trafficking in women and children, health, education, are concrete examples of welfare issues that are considered to be important women issues.

The road to participation in politics and decision making remains a formidable challenge. This path is not easy when it turns out, the bonds of women who are in decisionmaking positions with those outside are also not sustainable. The ideals that were carried out were with the presence of a number of women in decision-making positions, hoping to make better women's struggles with the assumption that as women they also have the same experience that can be more easily understood. Thus, it is important to explore how the understanding of women in formal political institutions on the various issues, needs and interests of women are urgent to strive for. Is the struggle in formal political institutions a strategic step in fighting for women's interests? Is the inclusion of women activists in practical politics an indication of the strengthening of the women's movement?

This research was conducted in Malang with several considerations; there are some women politicians who are actively voicing women's interests; there are several women's organizations active in fighting for women's rights; there are several teachers of political science who helped educate the women in Malang. The data collection used informants or key actors [1]. Informants in this study are some women who come from two main groups. First, women directly involved in practical politics, as candidates and legislators. Second, women are experts in politics, such as women's organizations and political science lecturer.

\section{THE THEORY OF FEMINISM}

In this study, feminist perspectives are used to find out women's views on the various issues, needs and interests of women that are urgent to strive for. Whether the struggle in formal political institutions is a strategic step in fighting for the interests of women and whether the inclusion of women activists in practical politics is an indication of the strengthening of the women's movement.

Feminist theory is based on the simple question: "And what about the women?" In other words, where the women 
are in every situation investigated? When women do not play, what exactly are they doing? How do they experience the situation? What do they contribute to it? What does it mean to them? A significant number of women in Indonesia are potential in participating in the political process in Indonesia. Therefore, political education is a step for the empowerment of women's potential to determine the political process and nation-building.

The second fundamental question for feminists is: "Why is allthis happening?" This question requires an explanation of the social world itself. Women's awareness of their social world, which is socially and politically based on patriarchal culture, raises a question for women about the awareness of their social life.

The feminist perspective is a form of study that raises women's issues and views them with women's eyes. Lenggerman and Niebrugge [3] abstracted feminist perspectives on what attracts women as specific issues or themes of the study, and how women's perspectives respond to and explain the situation experienced by women.

So far the discussion of feminist contributions to science is still ongoing. There are some people who believe that feminist is a new paradigm. Neuman [1], in his discussion of the paradigm that are positivistic social sciences, social sciences and Critical Interpretative social sciences, adding the growth of two new a paradigm: feminists and postmodernists.

There are at least four tools of meaning and research practice in feminist studies, namely: feminists try to reconstruct all knowledge based on women's experiences and perspectives; women's studies try to come up with alternative qualitative approaches that take into account personal subjectivity and nuance; arguments about the generation and adjustment of subjectivity are also influenced by the idea of feminism concerning the necessity of direct interviews through the method of tracking subjectivity and also the use of a sisterhood of research perspectives; besides that feminists argue that there is no single methodology, on the contrary, there are many feminist theoretical approaches and research methods that are concerned with the context and status of knowledge and knower in social situations.

In contrast to previous studies, this study will look at feminist perspectives. Therefore, it is also necessary to change simultaneously defined as the new way of doing politics (politics in a new way). This concept is in response to feminist groups who see that involvement in formal institutions is not enough to explain the political activities of women. If so the terminology, then many political activities of women, most of whom are in the "private" space such as performing reproductive functions, taking care of the household, educating children, if quoting Jill Bystydzienski [4], all these activities have important political dimensions, and all activities it also has a political characteristic is the existence of unequal power relations between men and women. Social relationships characterized by unequal power relations are political relations.

In its development, feminist theories try to encapsulate the typical experience of women in scientific theories to enrich the academic world. It is believed by feminists that the original consciousness is personal and may then become political.

Smith developed a different women's experience than men who were put in a theoretical perspective. Gender experience is gained by women because of their presence in the home environment, neighbors and having relationships with other children and women. In addition, women's activities are in the domestic, household and maintenance and nurturing areas. Thus, women's attitudes and perceptions are at a certain locality.

\section{RESULTS}

Indonesia is filled by $57 \%$ of women. Speaking of women's interests in the legislation process is at least two things. First, the legislation that takes into accounts the interests of vulnerable groups including women and children. Secondly, the participation of women in the legislative process, both are interrelated and influence each other [4].

In reality, women's interests are often ignored on the basis of often irrational arguments. For example, in the discussion of the Household Domestic Violence Bill (Rancangan Undang-Undang), the issue of domestic violence is considered an ordinary dispute and not a form of violence that in fact has affected thousands of women in Indonesia. One member of the Special Committee (Panitia Khusus) discussing the bill states that if someone else interferes in his household affairs-even if he is violating his wife-he will kill the person interfering in his "affairs". Some other members of the Special Committee are concerned that the existence of this law is a tool for bringing men to justice and bringing the effects of divorce and contrary to the spirit of uniting families promoted by the Marriage Act.

According to informants, the pressing issues of women's issues, needs and interests are similar to those of women at the national level. The problems mentioned above, is a problem that also occurs in the region. So, issues the women according to the informants was limited to matters relating to the welfare and have not touched on the new paradigm shift that is responsive to the interests and policies for women's empowerment.

\section{IV.The STRUGGLE OF WOMEN: InFORMAL POLITIC}

Basically, women's political participation in local politics has been technically stated to be guaranteed by various regulations, both at the international, national and local levels, both explicit and implicit. The formulation of women's participation in local politics here is the formulation of local regulations that ensure that women can sit in formal political institutions so that women can formulate policies that benefit women themselves. The formulation of women in local public policy referred to here is the formulation of a regional regulation that regulates women's activity or the space and appearance of women in the public domain.

The gender composition of legislators can also be used as a reference to see and compare opportunities for the political participation of both gendered through elections. The definition of citizen political participation is a topic widely discussed in feminist political theories. Ruth Lister [5] summarizes the ideas of feminist scholars about the role 
of citizens, especially the rights and duties of citizens in relation to political participation. In Indonesia, women are regarded as citizens, without any explicit distinction in rights and duties with male citizens. But the important thing is to distinguish between active role and passive role as citizen. Lister quotes Mary Dietz as stating that political participation is a term that opposes the passive role of citizens as 'rights-holders'. Political participation means actively doing something in terms of obligation as a citizenthat is influencing public policy. Lister quotes Diemut Bubeck as suggesting that domestic work and nurturing should also be the duty of the citizens, so that this workload is not only placed on the shoulders of women and prevents women from having a wider space of possibility to move, without hindering cultural obligations as the domestic executives charged to her.

Gender mainstreaming is not possible without recognizing local women's issues and, more importantly, listening to women's voices. Decision-making requires sufficient knowledge and information on women's issues, and will be very useful if it involves women. The gap shows that very few women occupy formal structural positions in government. This suggests that the position of women in formal political institutions is much less than that of men.

Access limitations make it difficult for women to show that their interests are not contained in the existing political system. The limited involvement of women in the public sphere also becomes an obstacle to developing women's organizations in formulating women's interests. Therefore there must be room for the possibility of developing opportunities for women to define a system of participation that allows things beyond masculinity to be noticed. Luce Irigaray [6] in his discussion of the language system states that women find it difficult to articulate views to men and women because they do not find a suitable way of expression in the masculine order available in the language.

Some opinions from informants about the struggle made by women through formal political institutions in Malang are as follows:

- According to some informants, the contribution and influence of women are different than men, they explain that patriarchal culture inhibits women's activities, because women are often hampered by confidence, ability and culture. Not to mention when there is a challenge of having to deal with men who have an interest in maintaining the status quo.

- Another opinion says that women actually have an important contribution to community development, especially in women's empowerment and raising women's issues. However, women's participation and influence are limited in areas considered soft or suitable for women such as economics and trade.

- There is an opinion that women are more suitable for politics because women are more patient and patient than men, and women are also considered more flexible in the community. In this sense, the personality of women is more suited to influence the present imposed political system.

- A very optimistic opinion suggests that occupying the position of power is not limited because of its gender. However, women should be able to prove that its existence is in a position of power in the political world because of its capabilities.

- Some informants say that the contribution and influence of women and men in politics are relatively similar. The contribution given depends on the individual's character and not the gender, and may even be a woman greater than the male. So actually the existence of women is very dependent on the quality of each individual.

- In addition, other arguments suggest that women's contribution and influence are limited because women can't occupy a higher power position than men. Although women have the ability to occupy high positions in the political world it is feared that women are still seen as weak by men. Therefore women are limited in positions, contributions and influences.

- The minimal number of women holding decisionmaking positions is considered by some informants very influential on the issues which have always been voiced by women.

\section{STRENGTHENING THE WOMEN MOVEMENT}

There are three records concerning the impact of regional autonomy on women. First notes, the tendency of strengthening of identity politics, politicization of religion, and cultural revitalization nuanced restriction public role of women. Second, regional autonomy does not necessarily improve the welfare a community, it is characterized by more budget allocations for local government implementation costs than the welfare of the community. Third, theactive participation of women in policy-making is still very minimal.

Of course the above concept is just an idea of the ideal type of management and implementation of regional autonomy in Indonesia. Because at least there are only three regions are given relative specificity for promotion of cultural values in the local communities in managing their respective regions, namely: Papua, Aceh and Yogyakarta. In the limited space for the area, they discovered a variety of efforts to develop a policy or policies distinctively regional culture. The presence of some of the regulations in a small area of policy to declare formalization distinctively Islamic values is one manifestation of the local culture. It shows the area continues to display its cultural identity, though in the process of defining the policy was still very elitist. The problem, when a region is going to show its cultural identity, at the same time it also develops the understanding and the human rights movement clashed with local cultural values.

The position of women in culture conditions as it will always be marginalized. The subordination of women who feared growing in the era of regional autonomy is a consequence of political management practices which affected four major factors in the decision making process in the area. First, the cultural domain is dominated by men. Second, the religious sphere is also ruled by men. Third, the economic sphere is also controlled by men, though in the process of economic management, the role of women is no less important than men. Fourth, this is the most decisive 
political arena dominated by men. Reality as it raises the ongoing tension for dealing with the development of human rights awareness a result of globalization.

To address the above issues, women will eventually have to take a stand as to what equality between women and men in regional autonomy. In this context it will be a lot of possibilities that may occur: First, in a public area of his human rights movement commonplace, including substantial aspects touching woman's position, there will be dynamics that allow the accommodation of the interests of women in policies related to Islamic law. Second, in which the domination of society autonomous region local culture is still very strong and there is no direct human rights movement, the women will only accept any political decisions (policies) are made without being able to fight any further.

The second possibility becomes likely that most of his chances will occur, given the regions in Indonesia in general is still very far from direct awareness of human rights, the most fundamental thing is actually that of any product of a policy issued by an autonomous, no need to worry if the policy is a product that is democratic and it is intended for the benefit of society in the autonomous region itself. There are several things that need to be fought by women which are trying to develop awareness in the community that the process of decision making at the local level should involve all the elements are there. Then the need for awareness of all sections of society that women are an element of people who become a major pillar in building local democracy, because the aspirations of women should be the primary consideration in the decision making process.

\section{The IMPORTANCE OF WOMEN'S POLITICS IN MALANG}

Very importantly increase the number of women and increase the influence of women in policy-making institutions in Malang. Three main reasons the importance of women's participation in Malang parliament, among others; First, improving gender equality in society Malang; Second, women focus on a few issues and legislation for the benefit of women; Third, women politicians have a symbolic importance, namely the awareness that women are important in politics, because this world are women.

With the presence of women in politics, it will be able to elevate the condition of women themselves who are still marginalized in some aspects of life. Because the women themselves who actually know how the problems they face. Female politicians can solve this problem through the implementation of gender-sensitive legislation that affects the lives of women in Malang. One informant says "I want to promote women because during this time, women did not have access to power and regulation", whereas women are important.

Women should be an inspirational example and actively encourage other women to enter the political sphere Malang. Striving to invite other women to be able to understand politics is very well. Better still if you can invite them to participate in politics, so they can fight for women's rights. Women politicians then excite and to be a motivator for other women, that politics is important for women in Indonesia.
According to some informants, gender budgeting plan, already entered into force, but women are very weak in monitoring and evaluation. Some informants explained that gender budgeting has been realized in the regional work units (Satuan Kerja Pemerintah Daerah / SKPD) and if done correctly can provide a good understanding of gender equality in society. If every SKPD realization of gender budgeting, and each district has a lot of SKPD, it will be many activities of gender-responsive can be done.

\section{CONCLUSION}

The interesting of women in legislative process involves two things, Firstly, the legislation that takes into account the interests of vulnerable groups including women and children. Secondly, the participation of women in the legislative process, both are interrelated and influence each other. Therefore, the issue of representation and participation of women becomes very significant. Although the government in some areas mentioned gender issues as one of the agenda to be executed, but not found the formulation of the participation of women in local politics explicit in the text of local regulations. Explicit formulation is important given the extensive involvement of women in decision making at the local level is very little.

There are three records regarding regional autonomy against women. Note first, the tendency of strengthening of identity politics, politicization of religion, and cultural revitalization nuanced restriction public role of women. Second, regional autonomy does not necessarily improve the welfare of the community it is characterized by more budget allocations for local government implementation costs than the welfare of the community. Third, the active participation of women in policy-making is still very minimal. There are several things that need to be fought by women which are trying to develop awareness in the community that the process of decision making at the local level should involve all the elements are there. Then the need for awareness of all sections of society that women are an element of people who become a major pillar in building local democracy, because the aspirations of women must be taken into consideration in the decision making process.

\section{REFERENCES}

[1] Neuman W Lawrence, "Social Research Methods: Qualitative and Quantitative Approaches," fifth ed. Boston: Pearson Education, Inc, 2003, pp 38, 87-91, 449.

[2] Ritzer Soetjipto, Ani Widyani, (Women Politic is not an Eclipse) “Politik Perempuan Bukan Gerhana”, Jakarta: Kompas, 2005.

[3] Lengermann, Patria Madoo and Niebrugge, Gillian, "The Women Founders: Sociology and Social Theory 1830-1930," Illinois: Waveland, 2007.

[4] Bystydziensky, Jill, "Women Transforming Politics: Worldwide Strategies for Empowerment," Bloomington, IN: Indiana University Press, 1992.

[5] Lister, Ruth, "Citizenship Feminist Perspkectives," New York: New York University, 2003.

[6] Irigaray, Lucy, "An Press, Ethics of Sexual Difference”, NewYork: Cornell University Press, 1993. 